\title{
Simulation of soil heavy metal pollution environmental stress on plant growth characteristics in the presence of wastewater
}

\author{
Papaioannou D. ${ }^{1}$, Kalavrouziotis I.K. ${ }^{1}{ }^{,}$, Koukoulakis P.H. ${ }^{2}$, Papadopoulos F. ${ }^{2}$, Psoma P. ${ }^{2}$ and Mehra A. ${ }^{3}$ \\ ${ }^{1}$ School of Science and Technology, Hellenic Open University, Aristotelous 18, 26 335, Patras, Greece \\ ${ }^{2}$ Hellenic Agricultural Organization 'Demetra' Soil Science Institute, 570 01, Thermi, Thessaloniki, Greece \\ ${ }^{3}$ Greenwich Research \& Enterprise, University of Greenwich, Park Row, Greenwich, London SE10 9LS, U.K. \\ Received: 11/05/2018, Accepted: 17/09/2018, Available online: 26/09/2018 \\ *to whom all correspondence should be addressed: e-mail: ikalabro@eap.gr \\ https://doi.org/10.30955/gnj.002758
}

\begin{abstract}
Soil pollution was simulated by means of artificial heavy metal enrichment, in the presence of treated wastewater, and its effect on the growth characteristics of Beta vulgaris L. (red beets) i.e. on the dry matter yield, and on beet quality expressed in terms of dry matter heavy metal, nitrogen and crude protein content, was investigated in a greenhouse pot experiment. Twelve treatment combinations of heavy metals mixtures composed of $\mathrm{Zn}, \mathrm{Mn}, \mathrm{Cd}, \mathrm{Co}, \mathrm{Cu}, \mathrm{Cr}, \mathrm{Ni}$, and $\mathrm{Pb}$, with each one metal participating in the mixture at $0,2,4,6,8,10$, $12,14,16,18,20,22 \mathrm{mg} \mathrm{kg}^{-1}$ were applied, respectively. It was found that the increase of soil DTPA extractable heavy metal concentrations reflecting high soil pollution, decreased statistically significantly the beet dry matter $(\mathrm{dm})$ yield, but increased the metal and the, the nitrogen concentrations, and consequently, contributed statistisically significantly to the increase of beet crude protein yield.
\end{abstract}

Keywords: Beta vulgaris, heavy metals, nitrogen protein, soil pollution.

\section{Introduction}

The application of treated wastewater for irrigation of vegetables has been shown to be a very appropriate recycling option for environmental and economic purposes (Mufeed et al., 2011). Furthermore, it is a common practice in many countries the reuse of municipal wastewater in urban and periurban ecosystems (Pedrero et al., 2010). The main purpose of the water reuse in agriculture is to provide a sufficient quantity of high quality water for irrigation and to ensure food safety (Pedrero et al., 2010). The wastewater is reused mainly for agricultural irrigation and recharge of aquifers. In addition, treated wastewater contains fractions of organic matter, suspended solids, nutrients and trace contaminants (Kalavrouziotis et al., 2013). It is noteworthy that the application of wastewater on agricultural land involves environmental hazards as the wastewater may contain a range of metals, which are toxic when the thresholds are exceeded. Several studies have indicated that long-term irrigation with wastewater can increase the contents of toxic metals in soils (Kalavrouziotis et al., 2013).

Plants have a natural ability to extract elements from soil (i.e. micro-nutrients, to roots, shoots and fruits by means of biological processes (Kalavrouziotis et al., 2008). In many cases, vegetables using wastewater irrigation have normal appearance, without visual symptoms of contamination and are therefore consumed by humans (Preeti et al., 2015). However, vegetables which are cultivated in areas with high heavy metal content may have adverse consequences on human health due to the high level of these metals in the edible plant parts (Kalavrouziotis et al., 2008). In addition, heavy metals tend to bioaccumulate in plants and animals, consequently, entering the food chain (Levei et al., 2009).

Proteins are macromolecules which are considered as being the major work factors of living cells. Apart from the important physiological role of proteins in plants, they also constitute a major source of food for humans and animal. Among the plants that are popular in human beings, vegetables are important parts of the human diet because they constitute rich sources of carbohydrates, proteins, vitamins, minerals whilst also having significant antioxidative effects (Vicente et al., 2009). The food quality and crop growth are affected by heavy metal accumulation in soils (Fergusson, 1990). The extent of accumulation of heavy metals in toxic levels depends on the plant and heavy metal species (Alloway, 2013). The consumption of vegetables which are heavy metal contaminated may set a risk to human health and this is one of the most important aspects of food quality deterioration (Guerra et al., 2011). During the last decades, the emission of heavy metals into the environment has increased considerably, due to rapid industrialization, urbanization and excessive usage of agricultural improvers such as fertilizers, wastewater, and biosolids. According to Shahid et al. (2014), heavy metals may affect the structure of plant proteins and consequently the quality of these compounds. 
While the formation, accumulation and mechanisms of establishing tolerance to heavy metal pollutants have been studied by physiologists, nutritionists and other scientists, the quantitative effects of heavy metals on plant proteins under the presence of heavy metals and their effects on these vital compounds of plants have not been studied adequately. As the heavy metals are toxic and at higher levels pose health risk, it is necessary to study their quantitative changes of their presence in the plant. Therefore, the purpose of the present work is to study the effect of heavy metals were added to soil via wastewater reuse and artificial enrichment on the quality and quantity characteristics of Beta vulgaris L. proteins, studied in relation to beet yield, and nitrogen concentration.

\section{Materials and methods}

A greenhouse experiment was conducted in an agricultural area of Amaliada located in Western Greece, in order to study the heavy metal bioavailability effect on proteins of Beta vulgaris L. plants grown in an artificially polluted soil using a randomized block statistical design. Treated municipal wastewater was applied for irrigation of plants. The wastewater was used basically as a source of irrigation water. It may however contain heavy metals which can in the long run accumulate in the soil increasing their load in addition to those heavy metals added via enrichment. All these metals are reflected in soil analysis which was made at the completion of the experiment. The above procedure was necessitated by the fact that the wastewater due to each relatively low heavy metal content, can increase the soil pollution level after long time irrigation of crops. As the level of soil pollution due to reuse cannot be increased in the short time of the experiment, to the extent of causing problems to the plant, it was considered necessary to enrich the soil with various levels of heavy metal mixtures in order to create various levels of heavy metal load in the soil so that their impact can be more clear on the plants. The study of the quantitative effect of wastewater on plant growth was not included with the aims of the present work, as the wastewater was applied at the same level to all plants.

\subsection{Experimental soil}

The experimental soil was collected from the top layer (0-30 cm depth) of a non cultivated agricultural area of Amaliada and was analyzed by the methods which refer to paragraph 2.3 of the present work. The physicochemical characteristics of soil are presented in Table 1.

Approximately $600 \mathrm{~kg}$ of soil was collected and sieved by means of a plastic $2 \mathrm{~mm}$ sieve. Twelve treatments i.e. (T1-T12) were applied to soil, composed of a heavy metal mixtures ( $\mathrm{Zn}, \mathrm{Mn}, \mathrm{Cd}, \mathrm{Co}, \mathrm{Cu}, \mathrm{Cr}, \mathrm{Ni}$ and $\mathrm{Pb}$ ), where each one of these metals was participating in each of the twelve mixtures with $0,2,4,6,8,10,12,14,16,18$, 20 and $22 \mathrm{mg} \mathrm{kg}^{-1}$, respectively. The chemical compounds used as carriers of the above metals were $\mathrm{ZnSO}_{4} \cdot 7 \mathrm{H}_{2} \mathrm{O}, \mathrm{MnSO}_{4} \cdot \mathrm{H}_{2} \mathrm{O}, \mathrm{CuSO}_{4} \cdot 5 \mathrm{H}_{2} \mathrm{O}, \mathrm{Cd}\left(\mathrm{NO}_{3}\right)_{2} \cdot 4 \mathrm{H}_{2} \mathrm{O}$, $\mathrm{Co}\left(\mathrm{NO}_{3}\right)_{2} \cdot 6 \mathrm{H}_{2} \mathrm{O}, \quad \mathrm{Na}_{2} \mathrm{Cr}_{2} \mathrm{O}_{7} \cdot 2 \mathrm{H}_{2} \mathrm{O}, \quad \mathrm{Ni}\left(\mathrm{NO}_{3}\right)_{2} \cdot 6 \mathrm{H}_{2} \mathrm{O}, \quad$ and $\mathrm{Pb}\left(\mathrm{NO}_{3}\right)_{2}$, respectively. The application of each metal mixture treatment to each pot was made by preparing a solution of high concentrations which was then diluted to the above metal concentration per treatment, and added to the soil. The bottom of each pot was closed, to avoid loss of nutrients and heavy metals due to drainage and leaching.

Table 1. Physicochemical characteristics of the experimental soil

\begin{tabular}{|c|c|c|c|c|c|c|}
\hline Sand & \multirow{3}{*}{$\%$} & \multicolumn{2}{|l|}{56} & \multirow{2}{*}{$\begin{array}{c}\text { OM } \\
\text { EC }\end{array}$} & \multirow{2}{*}{$\begin{array}{c}\% \\
\mathrm{mS} \mathrm{cm}-1\end{array}$} & \multirow{2}{*}{$\begin{array}{l}2.11 \\
0.21\end{array}$} \\
\hline Clay & & 12 & & & & \\
\hline Silt & & 32 & & $\mathrm{pH}$ & & 6.2 \\
\hline Cd & Co & $\mathrm{Cr}$ & $\mathrm{Ni}$ & $\mathrm{Pb}$ & $\mathrm{N}-\mathrm{NO}_{3}$ & $\mathbf{P}$ \\
\hline \multicolumn{7}{|c|}{$\mathrm{mg} \mathrm{kg}^{-1}$} \\
\hline 0.04 & 0.42 & 0.03 & 2.8 & 0.9 & 25 & 6 \\
\hline $\mathrm{K}$ & $\mathrm{Mg}$ & $\mathrm{Ca}$ & $\mathrm{Fe}$ & $\mathrm{Zn}$ & $M n$ & $\mathrm{Cu}$ \\
\hline \multicolumn{7}{|c|}{$\mathrm{mg} \mathrm{kg}^{-1}$} \\
\hline 75 & 260 & $>2000$ & 20.09 & 2.3 & 33.6 & 88.6 \\
\hline
\end{tabular}

EC-electrical conductivity, OM-organic matter

\subsection{Wastewater collection and analysis}

Treated municipal wastewater, was collected from the municipal wastewater treatment plant of Amaliada. For the determination of the heavy metals, the treated municipal wastewater was processed by the method given by APHA (2012) and the microelements and heavy metals $\mathrm{Zn}, \mathrm{Mn}, \mathrm{Cu}, \mathrm{Cd}, \mathrm{Co}, \mathrm{Cr}, \mathrm{Ni}, \mathrm{Pb}$ were measured by atomic absorption with graphite oven, except of $\mathrm{Zn}$ which was measured only by simple atomic absorption spectrophotometer without the use of the graphite oven.

\subsection{Soil analysis methods}

The soil samples were air-dried, sieved through a $2 \mathrm{~mm}$ sieve and oven dried at $75{ }^{\circ} \mathrm{C}$ for $48 \mathrm{hrs}$. The dry soil samples were analyzed by the methods, as follows: soil mechanical analysis by the classical Bouyoucos method as modified by Gee and Or (2002); organic matter by the wet digestion procedure method of Walkley and Black (1934); $\mathrm{pH}$ measured on water extract of saturated paste, using a standard glass $\mathrm{pH}$ electrode and the conductivity by means of a conductivity meter. Available soil $\mathrm{P}$ was analyzed by Olsen et al. (1954), the exchangeable $\mathrm{Ca}^{2+}, \mathrm{Mg}^{2+}$, and $\mathrm{K}^{+}$by extraction with $\mathrm{NH}_{4} \mathrm{Ac}$, at $\mathrm{pH}=7.0$ (Lanyon et al., 1982) and were determined by inductively coupled plasma atomic emission spectroscopy (ISP-OES, Perkin Elmer, Optima 2100 DV, Shelton, USA). The soil extractable fraction of $\mathrm{Zn}, \mathrm{Fe}, \mathrm{Mn}, \mathrm{Cu}, \mathrm{Cd}, \mathrm{Pb}, \mathrm{Co}$, $\mathrm{Ni}$, and $\mathrm{Cr}$, which is considered available to plants, were extracted with diethylenetriaminepentaacetic acid (DTPA) method (Lindsay and Norvell, 1978) and measured by ICP-AES.

\subsection{Experimental plants}

After the soil preparation of the pots, six seeds of the test plant Beta vulgaris L. (beet) were sown in each pot followed by light irrigation with treated wastewater. The plants were regularly irrigated during the 3.5 month growth period. A total volume of $47 \mathrm{~L}$ treated wastewater, added to each pot during the growth plant period.

\subsection{Plant tissue analysismethods}

The plant samples were flushed with tap water until the complete removal of the soil particles. Subsequently, the 
plant parts, root, beet (the edible plant part) and leaf samples, were washed separately with deionized water; with dilute solution of $0.005 \% \mathrm{HCl}$, and also thoroughly washed by means of a special detergent (Alconox, $0.1 \%$ ) and rewashed repeatedly four times, with distilled water. The samples of plant parts were left to drain on filter papers, dried in a ventilation oven at $70{ }^{\circ} \mathrm{C}$, and then they were weighted for the determination of dry matter, and grounded. In turn, a dry matter sample of $1 \mathrm{~g}$ was mineralized by dry ashing in a muffle furnace at $500{ }^{\circ} \mathrm{C}$ for 10-12 $\mathrm{h}$; then the ash was dissolved in a $5 \mathrm{ml} 6 \mathrm{~N} \mathrm{HCl}$ solution. The $\mathrm{Zn}, \mathrm{Mn}, \mathrm{Cu}, \mathrm{Cd}, \mathrm{Co}, \mathrm{Cr}, \mathrm{Ni}$, and $\mathrm{Pb}$ were measured by ICP-AES. Determination of total Nitrogen was realized by the Kjeldahl method and the Nitrogen Protein was estimated by multiplying the total Nitrogen by 6.25 (AOAC, 1990).

Table 2. Mean value of DTPA extractable soil heavy metal concentrations per treatment, determined at the finish of beet harvesting period

\begin{tabular}{|c|c|c|c|c|c|c|c|c|}
\hline \multirow{3}{*}{ Treatments } & \multicolumn{8}{|c|}{ Heavy metals in soil $\left(\mathrm{mg} \mathrm{kg}^{-1}\right)$} \\
\hline & \multicolumn{2}{|c|}{$\mathrm{Zn}$} & \multicolumn{2}{|c|}{$\mathrm{Mn}$} & \multicolumn{2}{|c|}{$\mathrm{Cu}$} & \multicolumn{2}{|c|}{ Cd } \\
\hline & mean & SD & mean & SD & mean & SD & mean & SD \\
\hline $\mathrm{T} 1$ & 1.28 & 0.10 & 32.35 & 2.50 & 85.51 & 5.83 & 0.09 & 0.03 \\
\hline $\mathrm{T} 2$ & 2.05 & 0.08 & 31.78 & 1.96 & 92.01 & 4.29 & 1.15 & 0.09 \\
\hline T3 & 2.49 & 0.28 & 29.08 & 2.88 & 89.03 & 5.24 & 2.23 & 0.15 \\
\hline $\mathrm{T} 4$ & 3.01 & 0.20 & 30.97 & 2.77 & 92.51 & 7.73 & 3.23 & 0.39 \\
\hline T5 & 3.72 & 0.11 & 36.57 & 2.24 & 90.17 & 4.67 & 4.16 & 0.55 \\
\hline T6 & 4.44 & 0.40 & 26.34 & 3.23 & 91.68 & 6.73 & 5.56 & 0.64 \\
\hline $\mathrm{T7}$ & 4.83 & 0.91 & 28.16 & 2.36 & 89.83 & 7.99 & 6.18 & 1.06 \\
\hline $\mathrm{T} 8$ & 5.95 & 0.22 & 26.88 & 2.82 & 101.46 & 4.48 & 8.19 & 0.41 \\
\hline T9 & 6.60 & 0.50 & 26.56 & 2.39 & 100.34 & 4.47 & 9.81 & 0.39 \\
\hline T10 & 7.88 & 0.79 & 25.44 & 3.25 & 102.57 & 7.60 & 10.76 & 0.84 \\
\hline T11 & 9.85 & 0.69 & 25.38 & 2.68 & 103.39 & 5.54 & 11.82 & 0.79 \\
\hline T12 & 10.18 & 0.88 & 23.72 & 3.93 & 102.25 & 11.57 & 14.07 & 1.97 \\
\hline \multirow{2}{*}{ Treatments } & \multicolumn{2}{|c|}{ Co } & \multicolumn{2}{|c|}{$\mathrm{Cr}$} & \multicolumn{2}{|c|}{$\mathrm{Ni}$} & \multicolumn{2}{|c|}{$\mathrm{Pb}$} \\
\hline & mean & SD & mean & SD & mean & SD & mean & SD \\
\hline $\mathrm{T} 1$ & 0.13 & 0.00 & 0.02 & 0.02 & 1.65 & 0.15 & 1.16 & 0.3 \\
\hline $\mathrm{T} 2$ & 0.19 & 0.01 & 0.03 & 0.02 & 2.36 & 0.18 & 1.67 & 0.17 \\
\hline T3 & 0.23 & 0.01 & 0.02 & 0.01 & 2.75 & 0.18 & 2.45 & 0.25 \\
\hline T4 & 0.32 & 0.03 & 0.04 & 0.02 & 3.53 & 0.37 & 3.15 & 0.08 \\
\hline T5 & 0.46 & 0.05 & 0.05 & 0.03 & 4.86 & 0.43 & 3.94 & 0.19 \\
\hline T6 & 0.44 & 0.03 & 0.04 & 0.02 & 5.42 & 0.56 & 5.39 & 0.66 \\
\hline $\mathrm{T7}$ & 0.46 & 0.06 & 0.07 & 0.04 & 5.86 & 0.81 & 5.99 & 0.72 \\
\hline T8 & 0.52 & 0.05 & 0.10 & 0.01 & 6.82 & 0.17 & 6.88 & 0.37 \\
\hline T9 & 0.65 & 0.07 & 0.09 & 0.01 & 8.09 & 0.49 & 8.18 & 0.39 \\
\hline T10 & 0.62 & 0.10 & 0.10 & 0.04 & 8.62 & 0.86 & 8.85 & 0.93 \\
\hline T11 & 0.73 & 0.04 & 0.18 & 0.05 & 9.28 & 0.46 & 9.97 & 0.81 \\
\hline T12 & 0.80 & 0.16 & 0.22 & 0.06 & 11.15 & 0.46 & 11.38 & 1.36 \\
\hline
\end{tabular}

SD: standard deviation ( $N=48$ and each value is mean of 4 samples)

Table 3. Dry matter yield of Beta vulgaris of the above ground plant part, beet, root and whole plant produced per treatment

\begin{tabular}{|c|c|c|c|c|c|c|c|c|}
\hline \multirow{3}{*}{ Treatments } & \multicolumn{8}{|c|}{ Plant dry matter (g) } \\
\hline & \multicolumn{2}{|c|}{ above ground } & \multicolumn{2}{|c|}{ beet } & \multicolumn{2}{|c|}{ root } & \multicolumn{2}{|c|}{ whole plant } \\
\hline & mean & SD & mean & SD & mean & SD & mean & SD \\
\hline $\mathrm{T} 1$ & 1.89 & 0.44 & 6.86 & 0.97 & 0.27 & 0.02 & 9.02 & 1.38 \\
\hline $\mathrm{T} 2$ & 2.44 & 0.52 & 5.87 & 0.75 & 0.35 & 0.09 & 8.65 & 1.09 \\
\hline T3 & 2.23 & 0.55 & 6.83 & 1.74 & 0.31 & 0.07 & 9.37 & 1.59 \\
\hline $\mathrm{T} 4$ & 2.46 & 0.29 & 5.77 & 1.56 & 0.38 & 0.11 & 8.62 & 1.56 \\
\hline T5 & 2.22 & 0.25 & 5.78 & 0.85 & 0.31 & 0.06 & 8.31 & 0.76 \\
\hline T6 & 2.43 & 0.49 & 5.13 & 0.62 & 0.29 & 0.06 & 7.85 & 0.85 \\
\hline $\mathrm{T7}$ & 3.03 & 0.43 & 7.20 & 0.96 & 0.45 & 0.17 & 10.68 & 1.14 \\
\hline T8 & 2.02 & 0.57 & 5.36 & 0.18 & 0.34 & 0.15 & 7.71 & 0.59 \\
\hline T9 & 2.15 & 0.59 & 4.75 & 0.61 & 0.23 & 0.05 & 7.13 & 0.48 \\
\hline T10 & 2.14 & 0.79 & 5.32 & 0.85 & 0.29 & 0.09 & 7.75 & 1.59 \\
\hline T11 & 2.32 & 0.52 & 5.90 & 1.19 & 0.48 & 0.19 & 8.70 & 1.70 \\
\hline T12 & 2.21 & 0.45 & 3.62 & 0.78 & 0.35 & 0.06 & 6.18 & 0.89 \\
\hline
\end{tabular}

SD: standard deviation ( $N=48$ and each value is mean of 4 samples) 
Table 4. Heavy metals concentrations of beets dry matter $\left(\mu \mathrm{g} \mathrm{g}^{-1}\right)$

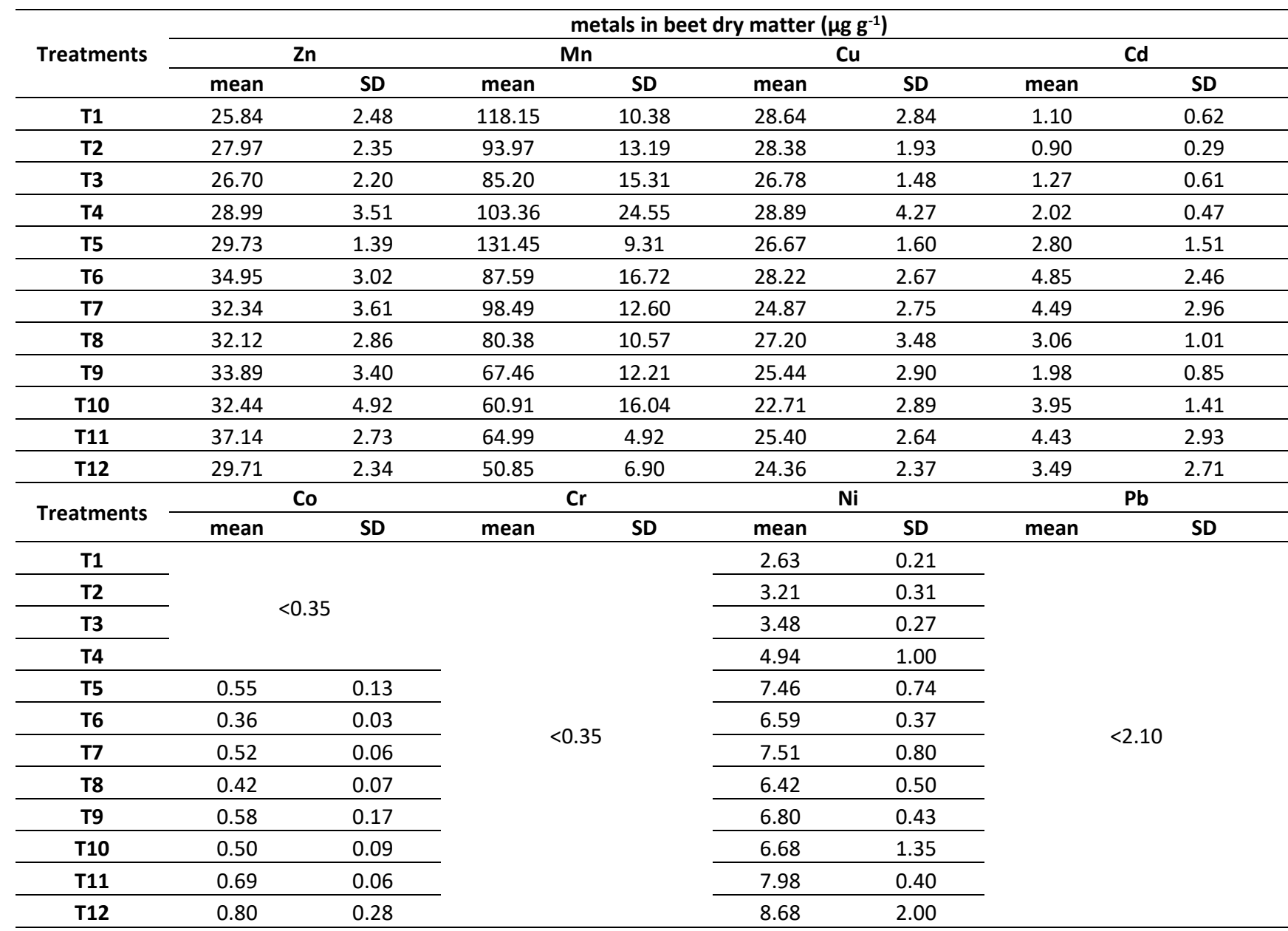

SD: standard deviation ( $N=48$ and each value is mean of 4 samples), ND: not detected

\subsection{Statistical analysis}

The experimental data were statistically analyzed by using the SPSS (21) program, running regression analysis and ANOVA.

\section{Results and discussion}

The relationship of heavy metals to beet quality of the edible plant part was studied in relation to the effect of heavy metals on beet yield, N, and crude protein content of beet dry matter.

\subsection{Effect of soil heavy metal levels to plant beet yield}

The applied treatments increased significantly the extractable heavy metal concentration in soil $(\mathrm{Zn}, \mathrm{Mn}, \mathrm{Cu}$, $\mathrm{Cd}, \mathrm{Ni}, \mathrm{Pb}$ ) (Table 2). Due to the above increase of available metal concentrations in soil the dry matter yield of beets and of the whole plant decreased significantly while the root and above ground parts dry matter yield was decreased statistically not significant (Table 3).

In Figure 1, the regression between $\mathrm{Zn}$ and beet dry matter yield as well $\mathrm{Cd}$ and beet dry matter yield, was found linearly negative and statistically significant. This figure emphasizes the toxic effect of the high available soil heavy metal levels on plant growth. These findings are in agreement with the results of Singh and Agrawal (2010), who found that Beta vulgaris grown in wastewaters containing a range of heavy metals reduced the plant yield. They related the higher bioavailability of heavy metals in wastewater irrigated sites to a reduction in the nutrient availability to plants, hence reducing the biomass.
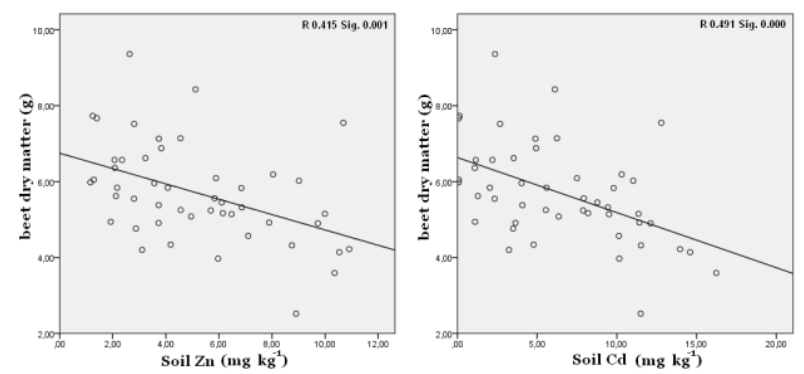

Figure 1. The effect of soil metals $\mathrm{Zn}$ and $\mathrm{Cd}$ on beet dry matter yield, under the influence of the applied heavy metal mixtures and wastewater reuse

\subsection{Effect of soil heavy metal composition on beets}

The concentrations of heavy metals in beet dry matter are reported in Table 4. Based on these data, it is shown that the soil heavy metals are transferred from soil to Beta vulgaris $\mathrm{L}$. in variable quantities. Factors which influence the transfer of metals from soil and their accumulation to plant are: (i) the soil type (ii) the metal concentration in the soil, (iii) the bioavailability of metals, (iv) the metal chemical forms, and $(v)$ the differences in uptake potential 
and growth rates of plant species (Tinker, 1981; Wang et al., 2012).

The relation of the heavy metal concentration in soil with that in beet tissue was found positive for the metals $\mathrm{Zn}$, $\mathrm{Mn}, \mathrm{Cd}, \mathrm{Co}$, and $\mathrm{Ni}$ where concentrations in the plant increased with the corresponding increasing soil concentrations, reflecting elevated soil pollution (Figure 2) and unfavorable effect of the beet quality. These results are important in the sense that the uptake of the heavy metals by the plants under soil pollution, and the possible harmful effects on consumer's health.
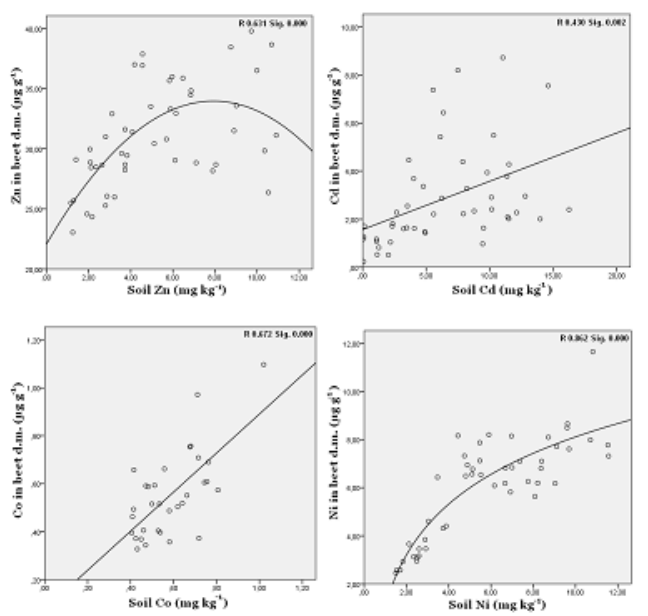

Figure 2. Relation between soil $\mathrm{Zn}, \mathrm{Cd}, \mathrm{Co}$ and $\mathrm{Ni}$ to their concentration in beet dry matter, under the effect of the applied metal mixtures treatments and wastewater reuse

\subsection{Effect of metals on beet $N$ concentration and crude protein yield}

The mean beet dry matter nitrogen concentration was positively affected by the applied treatments as shown in Figure 3. Consequently, the beet percent crude protein also increased with increasing heavy metal concentrations calculated by multiplying total $\mathrm{N}$ by the factor 6.25 (AOAC, 1990). The results are given in Table 5.

As shown in Figure 3, an increase of the applied levels of heavy metal concentrations in soil increased the percentage nitrogen content in the beet, respectively. Also, all the applied heavy metals, with the exception of $\mathrm{Cu}$, increased the beet crude protein content as shown in Table 6 and Figure 4 which is presents for example the interaction of $\mathrm{Zn}, \mathrm{Cd}, \mathrm{Ni}$ and Co. According to Shah and Dubey (1997), heavy metal stress has been shown to induce a variety of proteins, resulting in an overall increase in protein content. Singh and Agrawal (2007) also showed that the protein content of Beta vulgaris plants increased when grown in sludge amended soils with high concentrations of heavy metals. Metals in soils such as Fe, $\mathrm{Mn}, \mathrm{Zn}, \mathrm{Cu}$, and $\mathrm{Ni}$ are referred to as essential micronutrients for normal plant growth, and in tiny quantities have a pivotal role in the structure of enzymes and proteins (Zengin and Munzuroglu, 2005). However, the metals concentration is an important factor in the growing process of plants, and the existence in excess can lead to the reduction and inhibition of plant growth (Emamverdian et al., 2015).

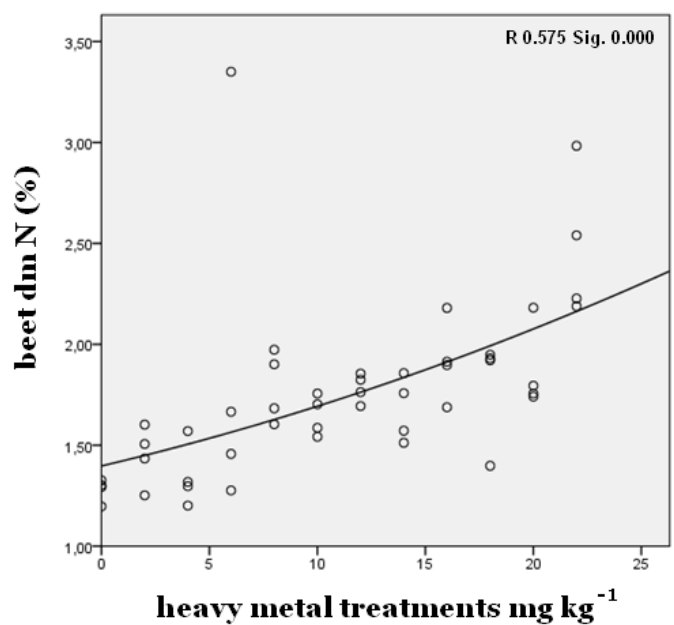

Figure 3. Effect of the metal treatments on the beet dry matter $\mathrm{N}$ contents

Table 5. Nitrogen protein expressed as percentages (\%) of the dry matter

\begin{tabular}{ccc}
\hline \multirow{2}{*}{ Treatments } & \multicolumn{2}{c}{ Nitrogen protein } \\
\cline { 2 - 3 } & \multicolumn{2}{c}{$\begin{array}{c}\text { expressed as percentages (\%) of the dry } \\
\text { matter }\end{array}$} \\
\cline { 2 - 3 } & mean & SD \\
\hline T1 & 8.00 & 0.36 \\
\hline T2 & 9.05 & 0.92 \\
\hline T3 & 8.42 & 0.98 \\
\hline T4 & 12.11 & 5.97 \\
\hline T5 & 11.19 & 1.09 \\
\hline T6 & 10.29 & 0.62 \\
\hline T7 & 11.15 & 0.44 \\
\hline T8 & 10.47 & 1,00 \\
\hline T9 & 12.00 & 1.26 \\
\hline T10 & 11.25 & 1.67 \\
\hline T11 & 11.68 & 1.31 \\
\hline T12 & 15.53 & 2.30 \\
\hline
\end{tabular}

The examination of the data of Table 6 reveals that almost all the heavy metals studied, either by the increase of their concentration in the soil or within the Beta vulgris L. plants, favorably affected the beet nitrogen content, therefore increasing the percent beet crude protein. The results in Figure 4 clearly show that the increase of DTPA extractable level of soil $\mathrm{Zn}, \mathrm{Cd}, \mathrm{Ni}$ and $\mathrm{Co}$, increases respectively the beet crude protein content and this increase is statistically significant (Table 6). The above findings are in line with the fact that $\mathrm{Zn}$ is an essential micronutrient taking part in the formation of proteins, known as zinc fingers that bind to DNA and RNA and contributes to their regulation and stabilization (Fergusson, 1990).

\subsection{Relation of heavy metal soil pollution to the beet} quality

The present work examines the beet quality in terms of dry matter heavy metal, $\mathrm{N}$, and crude protein percent. 

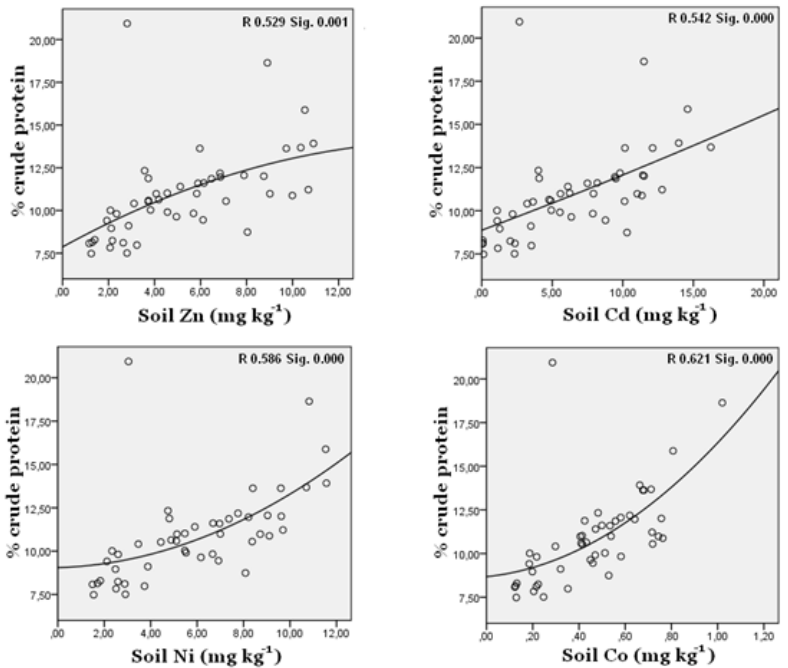

Figure 4. The effect of DTPA extractable soil $\mathrm{Zn}, \mathrm{Cd}, \mathrm{Ni}$ and $\mathrm{Co}$ in $\mathrm{mg} \mathrm{kg}^{-1}$, on beet percent crude protein under the effect of heavy metal mixture treatments and wastewater reuse

Examining the relation between the soil heavy metal pollution level, determined quantitatively by means of pollution indices such as Pollution Load Index (PLI), Elemental Pollution Index (EPI), Heavy metal Load (HML) and Total Concentration Factor (TCF) (Kalavrouziotis et al., 2012), it is interesting to underline that, based on Figure
5 , the beet dry matter crude protein content increases with the quantitative increase of soil heavy metal pollution. This result is in line with the effect of increasing individual heavy metal levels on beet $\mathrm{N}$ and on crude protein concentration as depicted by the Figures 3 and 4 .
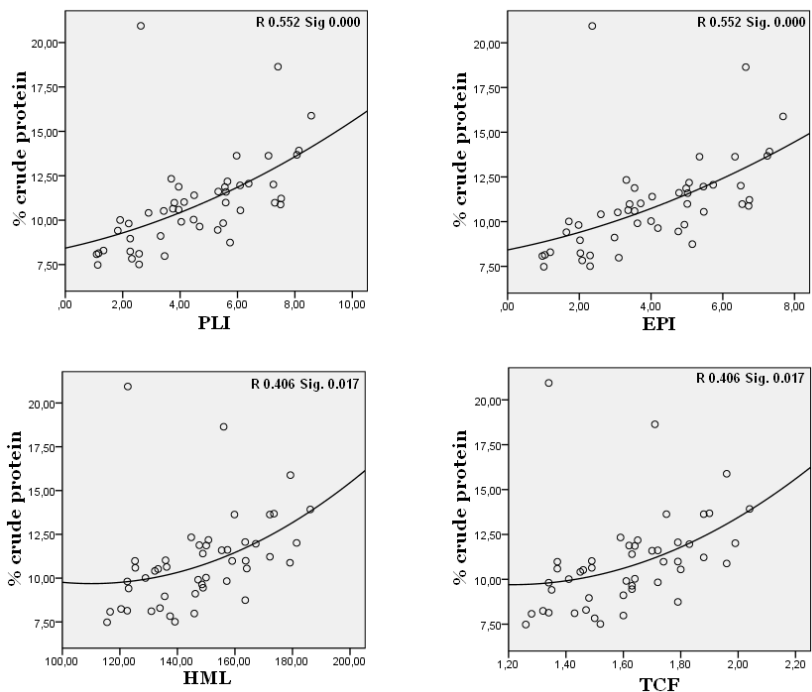

Figure 5. Relation of soil Heavy metal pollution indices to beet dry matter crude protein content under the heavy metal mixture treatments and wastewater

Table 6. Regression equations expressing the beet crude protein yield (CP) as a function of the soil heavy metals under the effect of the metals treatments studied and the wastewater reuse

\begin{tabular}{lllc}
\hline \multicolumn{1}{c}{ Regression equation } & $\mathbf{R}$ & significance & Type of regression \\
\hline $\mathrm{CP}=-0.002\left(\mathrm{Zn}_{\mathrm{s}}\right)^{2}+0.739\left(\mathrm{Zn}_{\mathrm{s}}\right)+7.87$ & 0.529 & 0.000 & $\mathrm{~S}$ \\
\hline $\mathrm{CP}=-6.422 \ln \left(\mathrm{Mn}_{\mathrm{s}}\right)+32.389$ & 0.372 & 0.009 & $\mathrm{~A}$ \\
\hline $\mathrm{CP}=6.337\left(\mathrm{Co}_{\mathrm{s}}\right)^{2}+1.334\left(\mathrm{Co}_{\mathrm{s}}\right)+8.675$ & 0.621 & 0.000 & $\mathrm{~S}$ \\
\hline $\mathrm{CP}=0.001\left(\mathrm{Cd}_{s}\right)^{2}+0.307\left(\mathrm{Cd}_{\mathrm{s}}\right)+8.837$ & 0.542 & $\mathrm{~S}$ \\
\hline $\mathrm{CP}=6.337\left(\mathrm{Co}_{\mathrm{s}}\right)^{2}+1.334\left(\mathrm{Co}_{\mathrm{s}}\right)+8.765$ & 0.621 & 0.000 & $\mathrm{~S}$ \\
\hline $\mathrm{CP}=-15.948\left(\mathrm{Cr}_{s}\right)^{2}+22.585\left(\mathrm{Cr}_{\mathrm{s}}\right)+9.29$ & 0.000 & $\mathrm{~S}$ \\
\hline $\mathrm{CP}=0.039\left(\mathrm{Ni}_{\mathrm{s}}\right)^{2}+0.037\left(\mathrm{Ni}_{\mathrm{s}}\right)+9.051$ & 0.004 & $\mathrm{~S}$ \\
\hline $\mathrm{CP}=0.002\left(\mathrm{~Pb}_{\mathrm{s}}\right)^{2}+0.419\left(\mathrm{~Pb}_{\mathrm{s}}\right)+8.449$ & 0.686 & 0.000 & $\mathrm{~S}$ \\
\hline
\end{tabular}

s: soil heavy metal, Type of regression: $A=$ antagonistic and $S=$ synergistic

\section{Conclusions}

Based the above mentioned, the following conclusions could be drawn:

The applied soil heavy metals treatments under the effect of the wastewater decreased the beet dry matter yield, due to the metal toxic effect. They, on the other hand, affected positively and statistically significantly the beet quality parameters, such as the total $\mathrm{N}$ concentration, the heavy metal content, and beet crude protein yield.

Also, the heavy metal soil pollution level, quantitatively determined by the use of the pollution indices, increased significantly the total beet $\mathrm{N}$ concentration and consequently the percent crude protein concentration of beets. These results showed that while the high concentration of soil heavy metals may have negative impact on beet biomass yield, but it can improve the beet protein quality parameter significantly.
It is concluded that more extensive research be conducted for the study of the heavy metal effect of the polluted soils on other quality parameters of beets, such as sugars and amino acids content.

\section{References}

Alloway B.J. (2013), Heavy Metals in Soils: Trace Metals and Metalloids in Soils and their Bioavailability, Environmental Pollution, 22, Springer Netherlands.

Emamverdian A., Ding Y., Mokhberdoran F. and Xie Y. (2015), Heavy metal stress and some mechanisms of plant defense response, The Scientific World Journal, Article ID 756120, DOI: $10.1155 / 2015 / 756120$.

Fergusson J.E. (1990), The Heavy Elements: Chemistry, Environmental Impact and Health Effects, Pergamin Press, Oxford, pp. 382-399.

Gee W.G. and Or D. (2002), Particle size analysis, In: Methods of Soil Analysis, Jacob H.D., Clarke T.G. and Vamen A.D., Madison, WI: Soil Science Society of America, pp. 151-184. 
Guerra F., Trevizam A.R., Muraoka T., Marcante N.C. and Canniatti-Brazaca S.G. (2011), Heavy metals in vegetables and potential risk for human health, Scientia Agricola, 69(1), 54-60.

Kalavrouziotis I.K., Kokkinos P., Oron G., Fatone F., Bolzonella D., Vatyliotou M., Fatta-Kassinos D., Koukoulakis P.H. and Varnavas S.P. (2013), Current status in wastewater treatment, reuse and research in some mediterranean countries, Desalination and Water Treatment, 53(8), 2015-2030.

Kalavrouziotis I.K., Koukoulakis P.H., Ntzala G. and Papadopoulos A.H. (2012), Proposed indices for assessing soil pollution under application of sludge, Water Air and Soil Pollution, 223, 5189-5196.

Kalavrouziotis I.K., Robolas P., Koukoulakis P.H. and Papadopoulos A.H. (2008), Effects of municipal reclaimed wastewater on the macro- and micro-elements status of soil and of Brassica oleracea var. Italica, and B. oleracea var. Gemmifera, Agricultural Water Management, 95, 419-426.

Lanyon L.E. and Heald W. (1982), Magnesium, calcium, strontium and barium, In: Methods of Soil Analysis Part 2: Chemical and Biological Properties, Page A.L., Miller R.H. and Keeney D.R. ASA, SSSA, Madison, pp. 247-262.

Levei E., Frentiu T., Ponta M., Senila M., Miclean M., Roman C., and Cordos E. (2009), Characterisation of Soil Quality and Mobility of $\mathrm{Cd}, \mathrm{Cu}, \mathrm{Pb}$ and $\mathrm{Zn}$ in the Baia Mare Area Northwest Romania Following the Historical Pollution, International Journal of Environmental Analytical Chemistry, 89(8), 635-649.

Lindsay W.L. and Norvell W.A. (1978), Development of the DTPA micronutrient soil test for zinc, iron, manganese and copper, Soil Science Society of American Journal, 42, 421-428.

Mufeed B.I., Aiman R., Kalavrouziotis I.K. and Koukoulakis P.H. (2011), Treated Municipal Wastewater Irrigation Impact on Olive Trees (Olea Europaea L.) at Al-Tafilah, Jordan, Water, Air and Soil Pollution, 217, 185-196.

Official Methods of Analysis (1990), vol. 15, Association of Official Analytical Chemists - AOAC, Washington D.C.

Olsen S.R., Cole C.V., Watanabe F.S. and Dean L.A. (1954), Estimation of Available Phosphorus in Soils by Extraction with Sodium Bicarbonate, USDA Circular Number 939, Washington, DC: U.S. Government Printing Office.

Pedrero F., Kalavrouziotis I., Alarcóna J.J., Koukoulakis P. and Asanoc T. (2010), Use of treated municipal wastewater in irrigated agriculture-Review of some practices in Spain and Greece, Agricultural Water Management, 97, 1233-1241.

Preeti V., Madhoolika A. and Sagar R. (2015), Assessment of potential health risks due to heavy metals through vegetable consumption in a tropical area irrigated by treated wastewater, Environment Systems and Decisions, 35(3), 375388.

Shah K. and Dubey R.S. (1997), Effect of cadmium on proline accumulation and ribonuclease activity in rice seedlings. Role of proline as a possible enzyme protectant, Biologia Plantarum, 40(1), 121-130.

Shahid M., Pourrut B., Dumat C., Nadeem M., Aslam M. and Pinelli E. (2014), Heavy-metal-induced reactive oxygen species: Phytotoxicity and physicochemical changes in plants, In: Reviews of Environmental Contamination and Toxicology, Vol. 232, Whitacre D.M. (Ed.), Springer International Publishing.
Singh A. and Agrawal M. (2010), Effects of municipal waste water irrigation on availability of heavy metals and morpho-physiological caracteristics of Beta vulgaris L., Journal of Environmental Biology, 31, 727-736.

Singh R.P. and Agrawal M. (2007), Effects of sewage sludge amendment on heavy metal accumulation and consequent responses of Beta vulgaris plants, Chemosphere, 67, 2229-2240.

Standard Methods for Examination of Water and Wastewater, American Public Health Association (2012), 22nd edition, APHA, AWWA, WEF, Washington D.C.

Tinker P.B. (1981), Levels, distribution and chemical forms of trace elements in food plants, Philosophical Transactions of the Royal Society London B Biological Sciences, 294(1071), 41-55.

Vicente A.R., Manganaris G.A., Sozzi G.O., Crisosto C.H. (2009), Nutritional Quality of Fruits and Vegetables. In: Postharvest Handling: A system Approach 5, Florkowski W.J., Shewfelt R.L., Brueckner B. and Prussia S. E. (Eds), Elsevier-Academic Press, pp. 57-106.

Walkley A. and Black I.A. (1934), An Examination of the Degtjareff method for determining soil organic matter, and $A$ proposed modification of the chromic acid titration method, Soil Science, 37(1), 29-38.

Wang Y., Qiao M., Liu Y., Zhu Y. (2012), Health risk assessment of heavy metals in soils and vegetables from wastewater irrigated area, Beijing-Tianjin city cluster, China, Journal of Environmental Sciences, 24(4), 690-698.

Zengin F.K. and Munzuroglu O. (2005), Effects of some heavy metals on content of chlorophyll, proline and some antioxidant chemicals in bean (Phaseolus vulgaris L.) seedlings, Acta Biologica Cracoviensia Series Botanica, 47(2), 157-164. 